\title{
Effects of Lactobacillus plantarum on intestinal integrity and immune responses of egg-laying chickens infected with Clostridium perfringens under the free-range or the specific pathogen free environment
}

\author{
Tianyue Xu, Yan Chen, Longfei Yu, Jun Wang, Mingxing Huang and Nianhua Zhu*
}

\begin{abstract}
Background: Necrotic enteritis, which is caused by Clostridium perfringens, has resulted in more than $\$ 2$ billion losses in the poultry industry every year. Due to the ban of antibiotics in feed industry, alternatives like environment improvement and probiotics have been found to be effective as well. In our study, we aim to explore the protective effect of Lactobacillus plantarum supplementation on CP infected chickens in two environments.

Results: The results showed that the Clostridium perfringens administration led to visible and histomorphological gut lesions. In the specific pathogen free or free-range system environment, dietary supplementation with $L P$ obvious increased the ratio of intestinal villus height to crypt depth and the expression of MUC2 mRNA in ileum mucosa, then reduced the mRNA expression level of TNF-a gene in the ileum mucosa. LP treatment significantly reduced the contents of total protein, total superoxide dismutase and glutamic oxaloacetic transaminase in serum of the chickens.

Conclusions: The specific pathogen free environment contributed to the recovery of pre-inflammation of the chickens, and free-range system environment contributed to the repair of damage in the later stages of chicken inflammation. Supplementation of $L P$ in FRS environment was more conducive to the recovery of $C P$ infected in chickens.
\end{abstract}

Keywords: Chickens, Lactobacillus plantarum, Clostridium perfringens, Environment, Intestinal injury score, Inflammatory cytokines

\section{Background}

Necrotic enteritis (NE), which is caused by Clostridium perfringens $(C P)$, is one of the most important enteric diseases in the global poultry industry which has resulted in about 6-7 billion US dollars loss per year [26]. C. perfringens type $\mathrm{A}$ is a gram-positive, spore-forming, rodshaped bacterium, which is the main pathogen that causes clinical and subclinical necrotic enteritis in poultry $[39,42]$. The key factor for the development of

\footnotetext{
* Correspondence: znh95@sina.com

Present address: Jiangxi Province Key Laboratory of Animal Nutrition, College of animal science and technology, Jiangxi Agricultural University, Nanchang, Jiangxi 330045, People's Republic of China
}

$\mathrm{NE}$ is the change of gastrointestinal environment, which creates favorable conditions for the growth of $C P$. Environment improvement (intensive feeding patterns) and the extensive use of antibiotics have played an important role in preventing $C P$ infection and the incidence of $\mathrm{NE}$ in the past decades [33]. Antibiotics are considered to be effective measures to reduce the incidence of $\mathrm{NE}$, but due to ban on feeding growth-promoting antibiotics in Europe, there has been an increase in the incidences of NE [14]. Owing to the ban on the use of antibiotics in feed industry, researchers have searching for alternatives to help growth-promoting and prevention of the incidence of NE.

(c) The Author(s). 2020 Open Access This article is distributed under the terms of the Creative Commons Attribution 4.0 International License (http://creativecommons.org/licenses/by/4.0/), which permits unrestricted use, distribution, and reproduction in any medium, provided you give appropriate credit to the original author(s) and the source, provide a link to the Creative Commons license, and indicate if changes were made. The Creative Commons Public Domain Dedication waiver (http://creativecommons.org/publicdomain/zero/1.0/) applies to the data made available in this article, unless otherwise stated. 
The European Union (EU) has completely banned the use of traditional laying hens from January, 2012 [35]. Laying hens are raised in large cages, with self-owned free-range feeding, shed flat feeding and organic feeding and other better ways of poultry breeding. Improving animal welfare is the key to improving bird health, quality of life and productivity [2]. A diet of mealworms and fresh grass contribute to improve gait score, chicken meat quality, produce higher platelet values and richer intestinal microorganisms in free-range environment [22]. Free-range environment can improve egg laying performance, promote feeding activities of chickens, and improve animal welfare. Specific pathogen free (SPF) animals were introduced in the 1960s to reduce disease or infection as a variable not required in their experiments [28]. Today, the overall strategy for most livestock industries is to incubate animals that do not contain infectious agents from sterile livestock or cesarean delivery aseptic techniques for experimental animal models of various diseases [11].

Probiotics are defined as a class of active microbial supplements that are beneficial to the host, improving host intestinal microbial balance and beneficially affecting the host [9]. A large number of studies have shown that probiotics have a variety of biological functions. They can produce molecules with antimicrobial activity, target specific pathogens, and even inhibit the adhesion of pathogens. They can also improve intestinal morphology, maintain intestinal microbial balance, and interact with host to improve immunity $[9,10,18]$. Lactobacillus plantarum and Lactobacillus casei are the most commonly used probiotics. Studies have shown that Lactobacillus casei can reduce the incidence of diarrhea, and interact with human mucosa, significantly reducing the release of inflammatory factors in Crohn's disease [8, 13, 29]. Studies have shown that $L P$ can improve the growth of weaned piglets, promote the development of small intestine villi, and increase serum IgM, IL-10 and TGF- $\beta$ levels [30].

The purpose of our experiment is to study the effect of $L P$ supplementation on immune function of chickens after infected with $C P$ in different environments. We aim to explore whether different feeding methods and probiotics can alleviate the adverse effects of necrotizing enteritis by $C P$ on chickens. We also aim to provide effective measures and a theoretical basis to aid in reduction of losses from NE in the poultry industry.

\section{Results}

Intestinal lesion score and immune organ index

There was no death of chickens in the whole experiment. Compared to the SPF environment, chickens fed in FRS environment had a higher intestinal lesion score at 1 st and 3rd day after exposure to $C P(P<0.01$, Fig. 1$)$, and then had lower score at 10th after $C P$ administration $(P<0.05) . L P$ had no significant effect on ileum injury score. All chickens administered with $C P$ had different degrees of ileum injury. FRS environment inflammatory response was more harmful in early stages, and recovery was faster in the later stage of inflammation, which indicated that the FRS environment was more conducive to the recovery of chickens.

The immune organ index of chickens after administration with $C P$ are shown in Table 3. SPF environment significantly increases the thymus index in the 1st and

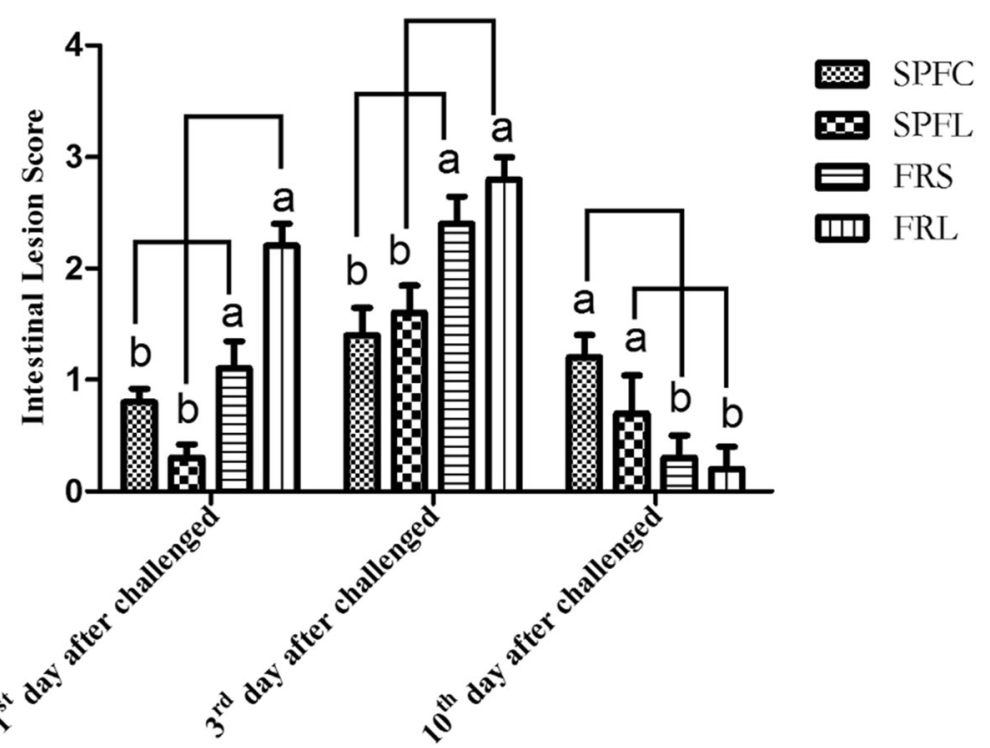

Fig. 1 The effect of Lactobacillus plantarum and environment on the ileum injury scoreThe different letters (a, b) of linear connection showed significant difference $(P<0.05)$ 
10th day after $C P$ administration $(P<0.05)$. FRS environment increased the bursa index in 1st day after chickens were administered with $C P(P<0.05) . L P$ treatment had an increasing trend on thymus index in 10th day after $C P$ exposure. The results indicated that the SPF environment enhances immune function by increasing the chicken thymus index, while the FRS environment enhances immune function by increasing the chicken bursa index.

\section{Observation and analyses on intestinal morphology}

Difference of feeding environment and $L P$ treatment on duodenal morphology of chickens after $C P$ administration is showed in Table 4. Compared to SPF environment, the FRS environment can significantly increase the duodenal villus height $(P=0.035$, on 3rd day after $C P$ administration), the depth of crypt $(P<0.01$, on 1st, 3rd day after $C P$ administration), the $\mathrm{V} / \mathrm{C}(P=0.005$, on 10th day after $C P$ administration). $L P$ treatment increased the villus height and V/C $(P<0.05)$. Under the experimental conditions, the environment and $L P$ had an interaction effect on the duodenal villus height $(P=0.038$, on 10 th day after $C P$ administration), the depth of the crypt of the duodenum $(P<0.05)$, and the $\mathrm{V} / \mathrm{C} \quad(P<0.01$, on 1 st and 10th day after $C P$ administration).

Difference of feeding environment and $L P$ treatment on jejunal morphology of chickens after $C P$ administration is shown in Table 5. Compared to FRS environment, the SPF environment can significantly increase the jejunum villus height $(P<0.01$, on 3 rd and 10th days after $C P$ administration), and the V/C $(P<0.01) . L P$ treatment had an increasing effect on the $\mathrm{V} / \mathrm{C}(P<0.01)$. Under the experimental conditions, the environment and $L P$ had an interaction effect on the jejunum villus height $(P<0.05)$, the depth of the crypt $(P<0.05$, on 1 st day after $C P$ administration), and the $\mathrm{V} / \mathrm{C}(P<0.01$, on 1st and 3rd days after $\mathrm{CP}$ administration).

Difference of feeding environment and $L P$ treatment on ileal morphology of chickens after $C P$ administration is shown in Table 6. Compared to SPF environment, the FRS environment can significantly increase the ileal villus height $(P<0.01)$, and the depth of the crypt $(P<0.01)$. LP treatment increased the V/C $(P<0.01$, on 1st and 10th days after $C P$ administration). Under the experimental conditions, the environment and $L P$ had an interaction effect on the ileal villus height $(P<0.01$, on 1 st and 3rd days after $C P$ administration), the depth of the crypt $(P<0.05$, on 3rd and 10th day after $C P$ administration), and the $\mathrm{V} /$ $\mathrm{C}(P<0.01$, on 1 st and 3rd days after $C P$ challenged).

\section{Serum biochemical and immune parameters}

The results of serum biochemical indicators of chickens are shown in Table 7. Compared with the FRS environment, the SPF environment can significantly reduce the TP levels in the serum of chickens $(P=0.038$, on 10th day after $C P$ administration) and AKP levels $(P<0.05$, 3rd and 10th days after $C P$ administration). However, on 1st day after $C P$ administration, the FRS environment can significantly reduce the levels of GOT in the serum of chickens $(P=0.001)$, and the T-SOD has a tendency to decrease $(P=0.096)$. $L P$ treatment group can significantly reduce the levels of TP, TSOD and GOT in the serum of chickens $(P<0.05)$. Under the conditions of this test, the environment and $L P$ had an interaction effect on TP $(P=0.002$, on 3rd day after $C P$ administration) and AKP $(P=0.045$, on 10th day after $C P$ challenged).

The results of chicken serum immune index are listed in Table 8. Compared with the FRS environment, the SPF environment can significantly increase the serum IgA ( $P=0.044$, on 10 th day after $C P$ administration) and IgM $(P=0.041$, on 1 st day after $C P$ administration) levels in chickens. The $L P$ treatment group can significantly increase the serum levels of $\operatorname{IgA}(P<0.05$, on 3rd and 10th days after $C P$ administration), $\operatorname{IgM}(P=0.010$, on 10th day after $C P$ administration) and IgG $(P<0.05$, on 3rd and 10th days after $C P$ administration).

\section{Gene expression of ileal mucosal cytokines and tight junction proteins}

The expression results of the tight junction protein gene in the ileal mucosa of chickens are shown in Table 9. The LP treatment group can significantly promote the mRNA expression of $M U C 2$ gene $(P<0.05$, on 1 st and 3rd days after $C P$ administration) and Claudin gene ( $P=0.041$, on 3 rd day after $C P$ administration), and promoted mRNA expression of MUC2 gene $(P=0.072$, on 10th day after $C P$ administration) and Occludin gene $(P=0.082$, on 3 rd day after $C P$ administration). There was no significant difference on tight junction proteins between SPF and FRS environment. Under the conditions of this test, the environment and $L P$ had trends in interaction effect on the mRNA expression of $M U C 2$ gene $(P=0.060$, on 1 st day after $C P$ administration).

The results of gene expression of cytokines in ileal mucosa of chickens by $L P$ and environment are shown in Table 10. Compared with the FRS environment, the SPF environment has a tendency to decrease the expression of $I L-1 \beta$ gene mRNA $(P=0.086$, on 3 rd day after $C P$ administration). $L P$ treatment group can significantly reduce the expression of TNF- $\alpha$ gene $(P=0.022$, on 3rd day after $C P$ administration) and TLR4 gene $(P=0.039$, on 10th day after $C P$ administration) mRNA in the ileal mucosa of chickens.

\section{Discussion}

$C P$ is the main pathogen of avian NE and can also cause human gas gangrene and food poisoning [5]. As mentioned 
earlier, a loss of more than $\$ 2$ billion in poultry industry each year, is attributed to necrotizing enteritis which is caused by $C P$. In order to reduce losses, many measures (improve of the feeding style or environment, additive probiotic, i.e.) are used to competitively inhibit the growth of $C P$, improve the defense function of intestinal viscosity, and increase the immune function of chickens. Thymus is the main lymphoid organ in poultry, which is responsible for producing a variety of immune $\mathrm{T}$ cells [32]. Bursa of Fabricius is the main site of immunoglobulin synthesis, which plays an important role in cell-mediated immunity. The increase of thymus weight and relative weight of bursa of Fabricius (immune organ index) can reflect the increase of lymphocyte level. Kikuchi Y (2014) research shows that Lactobacillus plantarum can promote the proliferation and differentiation of $\mathrm{B}$ and $\mathrm{T}$ cells and improve the immune function of mice [21]. Our results show that SPF environment could increase the thymus index, and reduce the intestinal lesion in early stage of $C P$ infection, while the FRS environment had beneficial effect on recovery in the later stage, and increased the bursa index in early stage.

Studies have shown that chickens infected with $C P$ had a higher ileal injury score than unaffected chickens [6]. In our study, $L P$ had no significantly effect on ileum injury score, which may be due to the feeding time of $L P$ supplementation. However, SPF environment was conducive to early recovery of inflammatory response. FRS environment inflammatory response was more harmful in the early stage, and recovery was faster in the later stage of inflammation which indicated that the FRS environment was more conducive to the recovery of disease in chickens. This may be due to the fact that chickens in SPF environment were raised in isolators, and the air in SPF environment was cleaner than that in FRS environment. FRS environment had a great influence on the later stage of inflammation in chickens, which was because FRS environment can reduce fear, promote foraging activities of chickens, improve animal welfare, and enhance immune function through positive emotional state [2].

Gut microbiota can affect intestinal morphology through modifications of villus height and crypt depth [4]. $C P$ can directly damage intestinal mucosa, alter intestinal microflora, or damage the immune system [41]. The most obvious macroscopic lesions can be seen in the small intestine, the duodenum, the jejunum and the ileum, and sometimes the cecum, which are thin-walled, fragile, dilated and filled with gas [38]. Our results show that SPF environment and $L P$ can significantly increase the ratio of villus height and crypt depth in duodenum and jejunum of chickens, while FRS environment can significantly increase ileal villus height and crypt depth in chickens. Increasing crypt depth might contribute to intestinal regeneration and recovery of $\mathrm{NE}$ infected chickens. This is consistent with previous studies $[20,30]$. Studies have also shown that the intestinal microflora of chickens in FRS environment is more complex [1]. Lactobacillus plantarum had antagonistic activity against pathogenic microorganisms and spoilage microorganisms by producing organic acids, bacteriocins, and bacteriocin analogs $[19,27,36,37]$. Lactobacillus plantarum can promote the development of small intestine villi, and supplementation with Lactobacillus acidophilus in the diet had a tendency to increase the height of the small intestine villi [25]. The results obtained herein mean that $L P$ has the ability to maintain mature and functionally active epithelial cells. These results also suggest that SPF and FRS environments may effectively mitigate NE-induced intestinal injury by improving intestinal integrity, intestinal morphology and intestinal microbial balance in chickens.

After chickens were infected with $C P$ or on the subclinical infection of NE, the small intestine was damaged $[12,23]$. The intestinal injury may cause $C P$ to reach the bile duct and portal vein blood flow [24]. The association with hepatitis or biliary hepatitis [17] resulted in rise of the levels of T-SOD, AKP and GOT in serum of chicken. Our experiment showed that $L P$ treatment reduced the content of T-SOD, GOT and AKP, and increased the levels of IgA, IgM and IgG in the serum of chickens. These results mean that $L P$ could restore the antioxidant capacity and improve immune function of chickens. In addition, IgA in poultry was present in most intestinal cells. The release of $\operatorname{sIgA}$ into the intestinal cavity through transepithelial transport and the neutralization or prevention of pathogen binding to the mucosal surface were widely considered to be essential to protect the mucosal surface from toxins, viruses and bacteria [40].

Some bacterial pathogens can impair intestinal barrier function by disrupting tight junctions [31], such as $C P$, Clostridium difficile [34]. IL-1 $\beta$ was a major proinflammatory cytokine that induced its own expression and expression of other pro-inflammatory cytokines, such as the chemokine TNF- $\alpha$, which triggers inflammatory response by activating TLR-mediated signaling pathways [16]. Previous studies have shown that the mRNA expression of $I L-1 \beta$ will increase in the jejunum of chickens infected with $C P$ [25]. Meantime, our experimental results showed that $L P$ treatment increased the mRNA expression of MUC2 gene, Claudin and Occludin gene in ileum mucosa of chicken. The $L P$ treatment group can also significantly reduce the expression of TNF- $\alpha$ gene $(P=0.022$, on 3rd day after $C P$ administration) and TLR4 gene $(P=0.039$, on 10th day after $C P$ administration) mRNA in the ileum mucosa of chickens. These results suggested that $L P$ can protect intestinal epithelial barrier integrity from intestinal pathogens 
adhesion and invasion and improve intestinal health of $C P$ challenged chickens. This indicates that the SPF environment was conducive to the recovery of inflammatory response induced by $C P$, showing that the $L P$ treatment group could inhibit the colonization of $C P$ in the ileum and restore the intestinal inflammation caused by $C P$.

\section{Conclusion}

In summary, the results of our study indicate that NE impairs the intestinal epithelial barrier of the chickens and induces intestinal injury in $C P$ induced model. The supplementation of $L P$ in a FRS environment is more conducive to enhancing the adhesion of $L P$ in the chicken small intestine, inhibiting the proliferation of $C P$, and thus more effectively controlling or preventing NE. For the early prevention of NE, the risk of chicken disease can be reduced by keeping the feeding environment clean and dry. Our study show that the free-range environment and the supplement with probiotics (such as Lactobacillus plantarum) are effective measures to prevent from NE in poultry industry.

\section{Methods}

\section{Experimental animals, diets, and treatments}

One hundred specific pathogen free (SPF) White Leghorns eggs were purchased from Beijing (Beijing Merial Vital Laboratory Animal Technology Co., Ltd.) and hatched in the laboratory. Eighty 1-day-old SPF chickens were randomly divided into four groups of 20 chickens each, a $2 \times 2$ factorial arrangement of treatments was used in this study:

Group A (SPFC): SPF environment, animals were fed the basal diet.
Group B (SPFL): SPF environment, animals were fed the basal diet $+L P$ cultures of $10^{8} \mathrm{cfu} / \mathrm{kg}$ feed.

Group C (FRC): FRS environment, animals were fed the basal diet.

Group D (FRL): FRS environment, animals fed the base diet + LP cultures of $10^{8} \mathrm{cfu} / \mathrm{kg}$ feed.

In all the groups, each chicken were orally administered $1 \mathrm{~mL} C P\left(1 \times 10^{8} \mathrm{cfu} / \mathrm{mL}\right.$.day $)$ at $36-42$ days of ages $(C P$ challenged). After the attacked with $C P$, the chickens were in low spirits, loss of appetite and diarrhea. Corn-soybean meal diets were formulated according to the nutrient requirements for white Leghorn as recommended by $\mathrm{Na}$ tional Research Council (1994). The diet composition and nutrient levels are shown in Table 1. All diets were crumbled and powdered. During the whole experimental period, chickens were free to eat and drink water.

\section{Preparation of $L P$ and $C P$}

First, the laboratory Lactobacillus (Lactobacillus plantarum R1.0320, $L P$ ) was activated on MRS agar (Aobox, China) plate. $L P$ was then mixed and incubated in MRS liquid medium for $24 \mathrm{~h}$ alone and the $L P$ liquid solution was diluted until the bacterial concentration reached $1 \times$ $10^{9} \mathrm{cfu} / \mathrm{mL}$ for feeding test. Type A CP was activated on trytose sulfite-cyloserine (TSC) agar plate (Qingdao Hope Bio-Technology Co., Ltd., China), and the anaerobic culture was incubated at $42{ }^{\circ} \mathrm{C}$ for $18 \mathrm{~h}$ in liquid thioglycolate medium. The cultured bacteria was then diluted until the bacterial concentration reached $1 \times 10^{8}$ $\mathrm{cfu} / \mathrm{mL}$.

\section{Samples collection}

After $C P$ administration, five birds per treatment $(n=5)$ were randomly chosen from different replicates. For the

Table 1 Composition and nutrient levels of basal diet

\begin{tabular}{|c|c|c|c|}
\hline Ingredients & Content \% & Calculated nutrient levels & \\
\hline Corn & 59.04 & Metabolizable Energy (MJ/kg) & 12.71 \\
\hline Soybean meal & 35.04 & Crude Protein (\%) & 21.45 \\
\hline Soybean oil & 3.00 & $\mathrm{Ca}(\%)$ & 0.87 \\
\hline DL- Methionine & 0.10 & Available phosphorous (\%) & 0.36 \\
\hline Choline chloride(50\%) & 0.05 & Methionine + Cystine (\%) & 0.77 \\
\hline Dicalcium phosphate & 1.30 & Lysine (\%) & 1.18 \\
\hline Limestone & 1.00 & & \\
\hline $\mathrm{NaCl}$ & 0.30 & & \\
\hline Vitamin premix ${ }^{a}$ & 0.04 & & \\
\hline Trace mineral premin ${ }^{b}$ & 0.10 & & \\
\hline mildew preventive & 0.03 & & \\
\hline
\end{tabular}


sample size of each group, we refer to the method of Han et al. (2016) and Bertran et al. (2018) [3, 15], who reported that five chickens in each group were selected for sampling at each time point and then carries out subsequent experimental operations. Chickens were rendered unconscious by intravenously injection of pentobarbital sodium ( $100 \mathrm{mg} / \mathrm{kg}$ body weight) just before slaughter. The chicken jugular vein was cut off and the bleeding blood was collected by collecting blood tubes. The collecting blood tubes were tilted at $45^{\circ}$ and left at rest for $2 \mathrm{~h}$ of $4{ }^{\circ} \mathrm{C}$. After the serum was precipitated, it was centrifuged for $10 \mathrm{~min}$ at $3000 \mathrm{rpm}$. The serum was divided into 1.5 $\mathrm{ml}$ centrifuged tubes for the detection of serum indexes. Serum biochemical indicators were detected with commercial reagent kits. Serum immune parameters were detected by ELISA method. Dissection was then carried out obtain spleen, thymus, and bursa of fabricius. They were weighed $(\mathrm{g})$ and the immune organ index was calculated. Immune Organ Index = Immune Organ Weight (g) / Live Chicken Weight (g). The duodenum, jejunum and ileum were taken, and rinsed with normal saline, and $2-3 \mathrm{~cm}$ of the middle part of the duodenum, jejunum and ileum were then taken, and placed in the $4 \%$ paraformaldehyde solution for fixation, and subsequent used for observation of intestinal morphology. The mucosa was scraped from the remaining ileum for inflammatory factor test.

\section{Intestinal lesion score}

Intestinal lesions were scored blindly according to the method of Truscott and Al Sheikhly (1977) [7] with slight modifications. Lesions were scored using a scale from 0 to 3 , in which $0=$ apparently normal, no obvious damage; $0.5=$ severe congestion of serosa and mesentery of small intestine; $1=$ thin walled and friable intestines with small red petechiae; 2 = gas in intestinal cavity, needle-like necrosis or ulcer spot in intestinal wall; $3=$ gas filled intestinal cavity, patches of necrosis or ulcer in intestinal wall ( 1 to $2 \mathrm{~cm}$ long).

\section{Intestinal morphological analyses and observation}

The duodenum, jejunum and ileum segments that were fixed in $4 \%$ paraformaldehyde, were embedded in paraffin. Tissue rings were cut to a thickness of $5 \mu \mathrm{m}$ and stained with hematoxylin and eosin. The slides were photographed with a Nikon microscope (NIKON INSTRUMENTS (SHANGHAI) CO., LTD. BA210). Villus height and crypts depth were measured from five villi and crypts per slide with the Motic Images Advanced (3.2) software and an average was taken. Villus height was defined as the distance from the villus tip to the villus-crypt junction, and the crypt depth was measured from the villus-crypt junction to the base of the crypt. The mean of villus height and crypt depth were calculated to obtain the villus height-to-crypt depth ratio (VCR). Morphological analyses and observation were conducted at magnifications of $100 \times$ for each slide.

\section{Determination of serum biochemical indicators and immune indicators}

Serum indicators were determined according to the manufacturer's instructions (Nanjing Jiancheng Bioengineering Institute, China). Biochemical indicators are: alkaline phosphatase (AKP), total protein (TP), albumin (ALB),

Table 2 Primer sequences of RT-PCR

\begin{tabular}{|c|c|c|c|}
\hline Target & Primer sequence $\left(5^{\prime}-3^{\prime}\right)$ & Accession no. & Product size (bp) \\
\hline \multirow[t]{2}{*}{ claudin-1 } & F:TCCAAGCTCACCAAAGAGGG & NM_001013611.2 & 128 \\
\hline & R:ACCGGTGACAGACTGGTTC & & \\
\hline \multirow[t]{2}{*}{$T L R 2$} & F:TACAGATGCTACTGTGCCTGA & NM_001161650.1 & 102 \\
\hline & R:CACTITCCAGTGCCCAAGAG & & \\
\hline \multirow[t]{2}{*}{ TLR4 } & F:TTCCATGGCTTAACGTCGCT & NM_001030693.1 & 82 \\
\hline & R:AGTGTCCGATGGGTAGGTCA & & \\
\hline \multirow[t]{2}{*}{ Occludin } & F:TGTGTAAGGCCCACACCTCT & NM_205128.1 & 92 \\
\hline & R:TGCTCAGGGTACCATTCTGG & & \\
\hline \multirow[t]{2}{*}{ TNF-a } & F:GAGCGTTGACTTGGCTGTC & XM_015294124.2 & 64 \\
\hline & R:GAGCGTTGACTTGGCTGTC & & \\
\hline \multirow[t]{2}{*}{$I L-1 \beta$} & F:ACTGGGCATCAAGGGCTA & XM_015297469.1 & 131 \\
\hline & R:GGTAGAAGATGAAGCGGGTC & & \\
\hline \multirow[t]{2}{*}{ MUC2 } & F:TTCATGATGCCTGCTCTTGTC & XM_421035 & 93 \\
\hline & R:CCTGAGCCTTGGTACATTCTTGT & & \\
\hline \multirow[t]{2}{*}{$\beta$-actin } & F:TTGTCCACCGCAAATGCTTC & NM_205518.1 & 106 \\
\hline & R:AGCCATGCCAATCTCGTCTT & & \\
\hline
\end{tabular}


Table 3 Effects of $L P$ and Environment on Immune Organ Index chickens after CP administration

\begin{tabular}{|c|c|c|c|c|c|c|c|c|c|}
\hline & \multicolumn{3}{|l|}{ 1st day } & \multicolumn{3}{|l|}{ 3rd day } & \multicolumn{3}{|c|}{ 10th day } \\
\hline & $\begin{array}{l}\text { Spleen } \\
\text { index }\end{array}$ & $\begin{array}{l}\text { Thymus } \\
\text { index }\end{array}$ & $\begin{array}{l}\text { Bursa } \\
\text { index }\end{array}$ & $\begin{array}{l}\text { Spleen } \\
\text { index }\end{array}$ & $\begin{array}{l}\text { Thymus } \\
\text { index }\end{array}$ & $\begin{array}{l}\text { Bursa } \\
\text { index }\end{array}$ & $\begin{array}{l}\text { Spleen } \\
\text { index }\end{array}$ & $\begin{array}{l}\text { Thymus } \\
\text { index }\end{array}$ & $\begin{array}{l}\text { Bursa } \\
\text { index }\end{array}$ \\
\hline$\overline{\text { SPFC }^{a}}$ & 0.20 & 0.65 & 0.42 & 0.18 & 0.67 & 0.38 & 0.22 & 0.60 & 0.41 \\
\hline SPFL & 0.16 & 0.57 & 0.49 & 0.19 & 0.64 & 0.40 & 0.18 & 0.67 & 0.39 \\
\hline FRC & 0.19 & 0.46 & 0.53 & 0.24 & 0.50 & 0.45 & 0.19 & 0.47 & 0.47 \\
\hline FRL & 0.18 & 0.51 & 0.61 & 0.22 & 0.61 & 046 & 0.19 & 0.57 & 0.46 \\
\hline SEM ${ }^{b}$ & 0.009 & 0.022 & 0.025 & 0.016 & 0.034 & 0.021 & 0.013 & 0.024 & 0.034 \\
\hline \multicolumn{10}{|l|}{ Main effects ${ }^{c}$} \\
\hline \multicolumn{10}{|l|}{ Environment } \\
\hline SPF & 0.18 & 0.61 & 0.45 & 0.19 & 0.65 & 0.39 & 0.20 & 0.64 & 0.40 \\
\hline FRS & 0.18 & 0.49 & 0.57 & 0.23 & 0.55 & 0.45 & 0.19 & 0.52 & 0.46 \\
\hline \multicolumn{10}{|l|}{ Lactobacillus } \\
\hline NLP & 0.19 & 0.55 & 0.47 & 0.21 & 0.59 & 0.41 & 0.21 & 0.54 & 0.44 \\
\hline LP & 0.17 & 0.55 & 0.55 & 0.20 & 0.62 & 0.43 & 0.19 & 0.63 & 0.42 \\
\hline \multicolumn{10}{|l|}{$P$-value } \\
\hline Environment & 0.884 & 0.015 & 0.030 & 0.179 & 0.167 & 0.163 & 0.831 & 0.021 & 0.385 \\
\hline Lactobacillus & 0.223 & 0.875 & 0.128 & 0.786 & 0.600 & 0.721 & 0.491 & 0.066 & 0.834 \\
\hline $\begin{array}{l}\text { environment } \times \\
\text { Lactobacillus }\end{array}$ & 0.500 & 0.152 & 0.898 & 0.586 & 0.330 & 0.906 & 0.469 & 0.944 & 0.948 \\
\hline
\end{tabular}

${ }^{a}$ Data of SFPC、SPFL, FRC and FRL were all average values.

${ }^{b} S E M$ meat standard error of mean.

'The data for the main effect represented average values.

The following table was the same.

Table 4 Effects of environment and $L P$ on the duodenal morphology of chickens after $C P$ administration

\begin{tabular}{|c|c|c|c|c|c|c|c|c|c|}
\hline & \multicolumn{3}{|c|}{ Villus height $(\mu \mathrm{m})$} & \multicolumn{3}{|c|}{ Crypt depth $(\mu \mathrm{m})$} & \multicolumn{3}{|l|}{$\mathrm{V} / \mathrm{C}$} \\
\hline & 1st day & 3rd day & 10th day & 1st day & $3 r d$ day & 10th day & 1st day & $3 r d$ day & 10th day \\
\hline SPFC & 954.42 & 961.49 & 1001.87 & 121.52 & 100.05 & $107 . .79$ & 8.56 & 10.25 & 9.75 \\
\hline SPFL & 1111.29 & 1017.62 & 1011.33 & 85.53 & 100.26 & 99.47 & 13.71 & 10.62 & 10.80 \\
\hline FRC & 822.79 & 1007.14 & 971.91 & 112.48 & 145.04 & 109.76 & 7.72 & 7.48 & 9.25 \\
\hline FRL & 1012.06 & 1067.21 & 1061.76 & 115.21 & 128.37 & 85.19 & 9.15 & 8.92 & 13.25 \\
\hline SEM & 13.059 & 11.228 & 9.662 & 1.950 & 2.097 & 1.514 & 0.244 & 0.179 & 0.170 \\
\hline \multicolumn{10}{|l|}{ Main effects } \\
\hline \multicolumn{10}{|l|}{ Environment } \\
\hline SPF & 1036.66 & 983.39 & 1006.57 & 102.65 & 100.13 & 103.65 & 11.26 & 10.39 & 10.27 \\
\hline FRS & 926.03 & 1040.66 & 1010.42 & 113.97 & 135.74 & 99.23 & 8.50 & 8.28 & 10.96 \\
\hline \multicolumn{10}{|l|}{ Lactobacillus } \\
\hline NLP & 895.26 & 981.96 & 986.99 & 117.46 & 120.23 & 108.77 & 8.18 & 9.01 & 9.50 \\
\hline$L P$ & 1064.59 & 1048.17 & 1032.94 & 99.49 & 117.57 & 93.35 & 11.57 & 9.57 & 11.85 \\
\hline \multicolumn{10}{|l|}{$P$-value } \\
\hline Environment & 0.000 & 0.035 & 0.597 & 0.009 & 0.000 & 0.043 & 0.000 & 0.000 & 0.005 \\
\hline Lactobacillus & 0.000 & 0.010 & 0.011 & 0.000 & 0.051 & 0.000 & 0.000 & 0.012 & 0.000 \\
\hline Environment $\times$ Lactobacillus & 0.536 & 0.930 & 0.038 & 0.000 & 0.045 & 0.008 & 0.000 & 0.135 & 0.000 \\
\hline
\end{tabular}


Table 5 Effects of environment and $L P$ on the jejunal morphology of chickens after CP administration

\begin{tabular}{|c|c|c|c|c|c|c|c|c|c|}
\hline & \multicolumn{3}{|c|}{ Villus height ( $\mu \mathrm{m})$} & \multicolumn{3}{|c|}{ Crypt depth $(\mu \mathrm{m})$} & \multicolumn{3}{|l|}{$\mathrm{V} / \mathrm{C}$} \\
\hline & 1st day & 3rd day & 10th day & 1st day & 3rd day & 10th day & 1st day & 3rd day & 10th day \\
\hline SPFC & 824.31 & 988.71 & 953.85 & 91.69 & 93.65 & 94.68 & 9.18 & 11.46 & 10.78 \\
\hline SPFL & 973.34 & 1057.00 & 957.08 & 70.47 & 79.29 & 84.60 & 14.45 & 14.48 & 11.74 \\
\hline FRC & 932.66 & 975.54 & 907.46 & 139.05 & 114.79 & 102.65 & 6.99 & 9.17 & 9.26 \\
\hline FRL & 872.28 & 836.24 & 843.10 & 98.61 & 95.90 & 83.80 & 9.08 & 9.13 & 10.50 \\
\hline SEM & 10.719 & 14.326 & 7.164 & 1.617 & 1.805 & 1.376 & 0.167 & 0.249 & 0.151 \\
\hline \multicolumn{10}{|l|}{ Main effects } \\
\hline \multicolumn{10}{|l|}{ Environment } \\
\hline SPF & 890.55 & 1014.05 & 955.43 & 82.26 & 88.325 & 89.74 & 11.52 & 12.58 & 11.25 \\
\hline FRS & 903.96 & 906.37 & 875.28 & 119.83 & 105.41 & 93.22 & 7.98 & 9.15 & 9.88 \\
\hline \multicolumn{10}{|l|}{ Lactobacillus } \\
\hline NLP & 885.14 & 982.34 & 930.98 & 118.28 & 103.87 & 98.61 & 7.95 & 10.35 & 10.03 \\
\hline$L P$ & 913.53 & 922.30 & 899.69 & 87.13 & 89.43 & 84.19 & 11.27 & 11.22 & 11.12 \\
\hline \multicolumn{10}{|l|}{$P$-value } \\
\hline Environment & 0.865 & 0.000 & 0.000 & 0.000 & 0.000 & 0.194 & 0.000 & 0.000 & 0.000 \\
\hline Lactobacillus & 0.040 & 0.216 & 0.034 & 0.000 & 0.000 & 0.000 & 0.000 & 0.003 & 0.000 \\
\hline Environment $\times$ Lactobacillus & 0.000 & 0.000 & 0.019 & 0.003 & 0.531 & 0.112 & 0.000 & 0.002 & 0.646 \\
\hline
\end{tabular}

total superoxide dismutase (T-SOD), glutamic oxaloacetic transaminase (GOT). The immune indicators are: IgA, IgM, IgG.

\section{RNA extraction and CDNA synthesis for gene expression analyses}

One hundred milligram of each ileum mucosa was ground in a $1.5 \mathrm{~mL}$ centrifugal tube along with $1 \mathrm{~mL}$ trizol (Takara Bio, Japan) with an electric homogenizer. The tissues were then fully shaken and placed at room temperature for $5 \mathrm{~min}$. Then, centrifugation was carried out at $12,000 \mathrm{rpm}$ for $10 \mathrm{~min}$ at $4{ }^{\circ} \mathrm{C}$. The supernatant was transferred to a new $1.5 \mathrm{~mL}$ centrifuge tube, and 0.2 $\mathrm{mL}$ of chloroform was added. It was violently shaken for $15 \mathrm{~s}$, and allowed to stand at room temperature for 5 min, followed by centrifugation at $12,000 \mathrm{rpm}$ for $10 \mathrm{~min}$

Table 6 Effects of environment and $L P$ on the ileal morphology of chickens after $C P$ administration

\begin{tabular}{|c|c|c|c|c|c|c|c|c|c|}
\hline & \multicolumn{3}{|c|}{ Villus height $(\mu \mathrm{m})$} & \multicolumn{3}{|c|}{ Crypt depth $(\mu \mathrm{m})$} & \multicolumn{3}{|l|}{$\mathrm{V} / \mathrm{C}$} \\
\hline & 1st day & 3rd day & 10th day & 1st day & 3rd day & 10th day & 1st day & 3rd day & 10th day \\
\hline SPFC & 531.29 & 478.77 & 547.09 & 64.04 & 60.28 & 75.80 & 8.39 & 8.15 & 7.79 \\
\hline SPFL & 702.84 & 504.61 & 570.35 & 65.72 & 59.20 & 68.50 & 11.02 & 8.61 & 8.79 \\
\hline FRC & 750.26 & 707.70 & 648.94 & 92.14 & 106.34 & 88.02 & 8.49 & 7.22 & 7.79 \\
\hline $\mathrm{FRL}$ & 759.81 & 518.52 & 662.89 & 88.42 & 90.50 & 69.06 & 9.09 & 6.02 & 9.88 \\
\hline SEM & 8.757 & 9.267 & 10.035 & 1.080 & 1.556 & 1.305 & 0.138 & 0.133 & 0.179 \\
\hline \multicolumn{10}{|l|}{ Main effects } \\
\hline \multicolumn{10}{|l|}{ Environment } \\
\hline SPF & 610.85 & 494.32 & 558.56 & 64.82 & 59.63 & 72.20 & 9.61 & 8.42 & 8.29 \\
\hline FRS & 755.00 & 602.30 & 655.62 & 90.29 & 97.51 & 78.95 & 8.79 & 6.55 & 8.79 \\
\hline \multicolumn{10}{|l|}{ Lactobacillus } \\
\hline NLP & 640.03 & 608.99 & 593.04 & 77.99 & 86.48 & 81.31 & 8.44 & 7.62 & 7.79 \\
\hline LP & 733.00 & 511.89 & 610.75 & 77.74 & 75.59 & 68.75 & 10.00 & 7.25 & 9.17 \\
\hline \multicolumn{10}{|l|}{ P-value } \\
\hline Environment & 0.000 & 0.000 & 0.000 & 0.000 & 0.000 & 0.015 & 0.001 & 0.000 & 0.129 \\
\hline Lactobacillus & 0.000 & 0.000 & 0.357 & 0.637 & 0.007 & 0.000 & 0.000 & 0.164 & 0.000 \\
\hline Environment $\times$ Lactobacillus & 0.000 & 0.000 & 0.818 & 0.213 & 0.018 & 0.026 & 0.000 & 0.002 & 0.129 \\
\hline
\end{tabular}


Table 7 Effects of $L P$ and environment on biochemical parameters in serum of chickens after $C P$ administration

\begin{tabular}{|c|c|c|c|c|c|c|c|c|c|c|c|c|c|c|c|}
\hline & \multicolumn{3}{|c|}{$\mathrm{TP}(\mathrm{g} / \mathrm{L})$} & \multicolumn{3}{|c|}{ ALB (g/L) } & \multicolumn{3}{|c|}{ T-SOD (U/mL) } & \multicolumn{3}{|c|}{ AKP (Gold unit / 100 ml) } & \multicolumn{3}{|l|}{$\begin{array}{l}\text { GOT } \\
\text { (IU/L) }\end{array}$} \\
\hline & $1 s t$ & $3 r d$ & 10th & $1 s t$ & $3 r d$ & 10th & $1 s t$ & $3 r d$ & 10th & $1 s t$ & $3 r d$ & 10th & $1 \mathrm{st}$ & $3 r d$ & 10th \\
\hline SPFC & 36.24 & 36.51 & 35.15 & 23.24 & 22.31 & 20.76 & 215.35 & 201.58 & 183.21 & 400.28 & 429.01 & 278.80 & 112.81 & 39.31 & 36.15 \\
\hline SPFL & 28.35 & 29.82 & 30.26 & 19.99 & 14.65 & 19.70 & 157.82 & 148.21 & 172.31 & 293.35 & 270.47 & 345.13 & 94.71 & 18.45 & 13.09 \\
\hline FRC & 40.70 & 34.00 & 48.21 & 22.79 & 21.31 & 22.54 & 168.76 & 170.59 & 194.69 & 647.49 & 788.63 & 656.74 & 73.38 & 36.59 & 29.51 \\
\hline FRL & 30.97 & 34.71 & 33.39 & 19.91 & 18.99 & 20.84 & 157.82 & 151.64 & 165.56 & 305.02 & 524.97 & 362.01 & 32.04 & 24.97 & 17.05 \\
\hline SEM & 0.899 & 0.425 & 1.630 & 0.306 & 0.825 & 0.403 & 6.250 & 4.795 & 3.166 & 36.526 & 53.607 & 38.121 & 4.869 & 1.265 & 1.798 \\
\hline \multicolumn{16}{|l|}{ Main effects } \\
\hline \multicolumn{16}{|l|}{ Environment } \\
\hline SPF & 32.30 & 33.16 & 32.71 & 21.61 & 18.48 & 20.23 & 186.58 & 174.89 & 177.76 & 346.81 & 349.74 & 311.96 & 103.76 & 28.88 & 24.62 \\
\hline FRS & 35.83 & 34.35 & 40.80 & 21.35 & 20.42 & 21.69 & 163.00 & 161.11 & 180.13 & 476.26 & 656.80 & 509.38 & 52.71 & 30.78 & 23.28 \\
\hline \multicolumn{16}{|l|}{ Lactobacillus } \\
\hline NLP & 38.47 & 35.26 & 41.68 & 23.02 & 22.08 & 21.65 & 192.05 & 186.08 & 188.95 & 523.88 & 608.82 & 467.77 & 93.10 & 37.95 & 32.36 \\
\hline LP & 29.66 & 32.26 & 31.82 & 19.95 & 16.82 & 20.27 & 157.53 & 149.92 & 168.94 & 299.19 & 397.71 & 353.57 & 63.38 & 21.71 & 15.35 \\
\hline \multicolumn{16}{|l|}{$P$-value } \\
\hline Environment & 0.085 & 0.199 & 0.038 & 0.679 & 0.275 & 0.108 & 0.096 & 0.189 & 0.718 & 0.114 & 0.021 & 0.032 & 0.001 & 0.475 & 0.717 \\
\hline Lactobacillus & 0.001 & 0.008 & 0.016 & 0.001 & 0.013 & 0.125 & 0.025 & 0.005 & 0.013 & 0.015 & 0.084 & 0.173 & 0.016 & 0.000 & 0.001 \\
\hline Environment $\times$ Lactobacillus & 0.623 & 0.002 & 0.166 & 0.770 & 0.184 & 0.702 & 0.103 & 0.110 & 0.188 & 0.146 & 0.637 & 0.045 & 0.267 & 0.106 & 0.171 \\
\hline
\end{tabular}

at $4{ }^{\circ} \mathrm{C}$. The supernatant was carefully pipetted into a new $1.5 \mathrm{~mL}$ centrifuge tube, and $0.5 \mathrm{~mL}$ of isopropanol was added. After mixing well, it was allowed to stand at room temperature for $10 \mathrm{~min}$, followed by centrifugation at $12,000 \mathrm{rpm}$ for $10 \mathrm{~min}$ at $4{ }^{\circ} \mathrm{C}$. The supernatant was discarded and $1 \mathrm{~mL}$ of $75 \%$ alcohol was added followed by centrifugation at $12,000 \mathrm{rpm}$ for $5 \mathrm{~min}$ at $4{ }^{\circ} \mathrm{C}$ (elution twice). The supernatant was discarded, and the sample was allowed to stand at room temperature for $10 \mathrm{~min}$. It was then dissolved in $30 \mu \mathrm{L}$ of DEPC water, and measured spectrophotometrically at $260 \mathrm{~nm}$. RNA purity was determined by measuring the ratio of absorbance readings of the RNA samples at 260 and $280 \mathrm{~nm}$ (A260 / A280). The A260/A280 ratio of all RNA samples was

Table 8 Effects of $L P$ and environment on immune parameters in serum of chickens after $C P$ administration

\begin{tabular}{|c|c|c|c|c|c|c|c|c|c|}
\hline & \multicolumn{3}{|c|}{$\lg \mathrm{A}(\mathrm{mg} / \mathrm{mL})$} & \multicolumn{3}{|c|}{$\operatorname{lgM}(\mathrm{mg} / \mathrm{mL})$} & \multicolumn{3}{|c|}{$\operatorname{lgG}(\mathrm{mg} / \mathrm{mL})$} \\
\hline & $1 s t$ & $3 \mathrm{rd}$ & 10th & $1 \mathrm{st}$ & $3 r d$ & 10th & $1 \mathrm{st}$ & $3 r d$ & 10th \\
\hline SPFC & 5.87 & 3.00 & 3.12 & 5.10 & 4.01 & 3.07 & 66.00 & 52.08 & 35.96 \\
\hline SPFL & 12.20 & 4.81 & 8.55 & 6.04 & 4.48 & 4.99 & 90.59 & 58.32 & 79.84 \\
\hline FRC & 1.97 & 2.44 & 3.06 & 4.04 & 4.81 & 4.29 & 57.48 & 36.88 & 37.18 \\
\hline FRL & 5.24 & 5.70 & 5.28 & 4.77 & 4.93 & 4.77 & 76.47 & 84.47 & 61.40 \\
\hline SEM & 1.689 & 0.474 & 0.350 & 0.239 & 0.175 & 0.179 & 5.500 & 5.924 & 5.096 \\
\hline \multicolumn{10}{|l|}{ Main effects } \\
\hline \multicolumn{10}{|l|}{ Environment } \\
\hline SPF & 9.04 & 3.90 & 5.84 & 5.58 & 4.25 & 4.03 & 76.54 & 55.20 & 54.77 \\
\hline FRS & 3.60 & 4.07 & 4.17 & 4.40 & 4.87 & 4.53 & 66.97 & 60.68 & 49.29 \\
\hline \multicolumn{10}{|l|}{ Lactobacillus } \\
\hline NLP & 3.92 & 2.72 & 3.09 & 4.57 & 4.41 & 3.68 & 61.74 & 43.63 & 36.64 \\
\hline LP & 8.72 & 5.25 & 6.91 & 5.40 & 4.70 & 4.88 & 82.52 & 72.85 & 68.32 \\
\hline \multicolumn{10}{|l|}{$P$-value } \\
\hline Environment & 0.146 & 0.867 & 0.044 & 0.041 & 0.114 & 0.196 & 0.326 & 0.651 & 0.413 \\
\hline Lactobacillus & 0.193 & 0.028 & 0.001 & 0.120 & 0.424 & 0.010 & 0.073 & 0.039 & 0.005 \\
\hline Environment $\times$ Lactobacillus & 0.663 & 0.468 & 0.051 & 0.839 & 0.637 & 0.078 & 0.804 & 0.103 & 0.353 \\
\hline
\end{tabular}


Table 9 Effects of $L P$ and environment on tight junction protein in ileum mucosa of chickens after $C P$ administration

\begin{tabular}{|c|c|c|c|c|c|c|c|c|c|}
\hline & \multicolumn{3}{|l|}{ MUC2 } & \multicolumn{3}{|c|}{ Claudin } & \multicolumn{3}{|c|}{ Occludin } \\
\hline & $1 s t$ & $3 \mathrm{rd}$ & 10th & $1 s t$ & $3 \mathrm{rd}$ & 10th & $1 s t$ & $3 \mathrm{rd}$ & 10th \\
\hline SPFC & 1.00 & 1.00 & 1.00 & 0.66 & 1.00 & 1.45 & 0.74 & 1.00 & 0.92 \\
\hline SPFL & 1.16 & 1.66 & 1.40 & 1.00 & 1.53 & 2.12 & 1.00 & 3.52 & 1.29 \\
\hline FRC & 0.64 & 0.63 & 0.49 & 1.07 & 0.57 & 0.72 & 0.41 & 0.40 & 0.28 \\
\hline FRL & 1.45 & 1.90 & 1.22 & 2.19 & 1.56 & 1.00 & 0.94 & 1.90 & 1.00 \\
\hline SEM & 0.076 & 0.137 & 0.142 & 0.324 & 0.163 & 0.422 & 0.270 & 0.531 & 0.310 \\
\hline \multicolumn{10}{|l|}{ Main effects } \\
\hline \multicolumn{10}{|l|}{ Environment } \\
\hline SPF & 1.07 & 1.25 & 1.15 & 0.85 & 1.20 & 1.78 & 0.88 & 1.94 & 1.01 \\
\hline FRS & 1.04 & 1.17 & 0.91 & 1.63 & 1.06 & 0.90 & 0.64 & 1.15 & 0.73 \\
\hline \multicolumn{10}{|l|}{ Lactobacillus } \\
\hline NLP & 0.84 & 0.84 & 0.81 & 0.89 & 0.84 & 1.09 & 0.58 & 0.73 & 0.60 \\
\hline$L P$ & 1.30 & 1.78 & 1.30 & 1.59 & 1.55 & 1.42 & 0.98 & 2.60 & 1.11 \\
\hline \multicolumn{10}{|l|}{$P$-value } \\
\hline Environment & 0.820 & 0.820 & 0.254 & 0.238 & 0.547 & 0.299 & 0.729 & 0.317 & 0.475 \\
\hline Lactobacillus & 0.011 & 0.005 & 0.072 & 0.278 & 0.041 & 0.587 & 0.479 & 0.082 & 0.400 \\
\hline Environment $\times$ Lactobacillus & 0.060 & 0.287 & 0.569 & 0.559 & 0.496 & 0.822 & 0.808 & 0.644 & 0.788 \\
\hline
\end{tabular}

between 1.8 and 2.0, indicating that the RNA samples were pure. Each sample was diluted according to the measured concentration and finally diluted to $1000 \mathrm{ng} /$ $\mu \mathrm{L}$. Each remaining RNA sample was stored at $-80^{\circ} \mathrm{C}$ for cDNA synthesis.

The manufacturer's instructions were followed (Takara Bio, Japan) and all operations were performed on ice. The above diluted $1000 \mathrm{ng} / \mu \mathrm{L}$ RNA sample was mixed with $2 \mu \mathrm{L}$ of each sample and $2 \mu \mathrm{L}$ of $5 \times$ DNA Eraser Buffer, $1 \mu \mathrm{L}$ of gDNA Eraser, and RNase Free $\mathrm{dH}_{2} \mathrm{O}$, and allowed to stand at room temperature for $15 \mathrm{~min}$. Then, $1 \mu \mathrm{L}$ of Primescript RT Enzyme Mix I, $1 \mu \mathrm{L}$ of RT Primer Mix, $4 \mu \mathrm{L}$ of $5 \times$ PrimeScript Buffer 2, $4 \mu \mathrm{L}$ of RNase Free $\mathrm{dH}_{2} \mathrm{O}$ were added, and placed in the PCR machine at $37^{\circ} \mathrm{C}$ for $15 \mathrm{~min}, 85^{\circ} \mathrm{C}$ for 5 seconds.

Table 10 Effects of $L P$ and environment on inflammatory factors of ileum mucosa of chickens after CP administration

\begin{tabular}{|c|c|c|c|c|c|c|c|c|c|c|c|c|}
\hline & \multicolumn{3}{|l|}{$\mathrm{IL}-1 \beta$} & \multicolumn{3}{|l|}{ TNF-a } & \multicolumn{3}{|l|}{ TLR2 } & \multicolumn{3}{|l|}{ TLR4 } \\
\hline & $1 \mathrm{st}$ & $3 r d$ & 10th & $1 \mathrm{st}$ & $3 \mathrm{rd}$ & 10th & $1 s t$ & $3 r d$ & 10th & $1 s t$ & $3 r d$ & 10th \\
\hline SPFC & 1.00 & 1.00 & 1.00 & 1.00 & 1.00 & 2.21 & 1.00 & 1.00 & 1.00 & 1.00 & 1.00 & 1.00 \\
\hline SPFL & 0.60 & 0.69 & 0.55 & 0.80 & 0.69 & 0.73 & 0.52 & 0.45 & 0.62 & 0.68 & 0.46 & 0.54 \\
\hline FRC & 0.67 & 1.72 & 1.25 & 1.71 & 1.15 & 1.00 & 0.83 & 0.59 & 1.90 & 0.83 & 1.00 & 1.51 \\
\hline FRL & 0.53 & 1.02 & 0.73 & 0.81 & 0.48 & 0.79 & 0.61 & 0.38 & 0.60 & 0.71 & 0.31 & 0.58 \\
\hline SEM & 0.147 & 0.140 & 0.108 & 0.122 & 0.093 & 0.132 & 0.141 & 0.197 & 0.258 & 0.130 & 0.204 & 0.147 \\
\hline \multicolumn{13}{|l|}{ Main effects } \\
\hline \multicolumn{13}{|l|}{ Environment } \\
\hline SPF & 0.80 & 0.88 & 0.83 & 0.93 & 0.86 & 1.47 & 0.79 & 0.75 & 0.86 & 0.86 & 0.80 & 0.83 \\
\hline FRS & 0.61 & 1.32 & 0.99 & 1.19 & 0.86 & 0.92 & 0.72 & 0.51 & 1.25 & 0.78 & 0.65 & 1.04 \\
\hline \multicolumn{13}{|l|}{ Lactobacillus } \\
\hline NLP & 0.82 & 1.27 & 1.09 & 1.27 & 1.07 & 1.45 & 0.93 & 0.79 & 1.34 & 0.92 & 1.00 & 1.19 \\
\hline LP & 0.56 & 0.88 & 0.64 & 0.81 & 0.60 & 0.76 & 0.56 & 0.42 & 0.61 & 0.69 & 0.38 & 0.56 \\
\hline \multicolumn{13}{|l|}{$P$-value } \\
\hline Environment & 0.510 & 0.086 & 0.349 & 0.171 & 0.860 & 0.055 & 0.880 & 0.552 & 0.416 & 0.795 & 0.859 & 0.372 \\
\hline Lactobacillus & 0.372 & 0.099 & 0.051 & 0.046 & 0.022 & 0.010 & 0.235 & 0.352 & 0.135 & 0.404 & 0.163 & 0.039 \\
\hline Environment $\times$ Lactobacillus & 0.667 & 0.505 & 0.873 & 0.176 & 0.347 & 0.037 & 0.664 & 0.667 & 0.398 & 0.709 & 0.865 & 0.438 \\
\hline
\end{tabular}




\section{Quantitative real-time RT-PCR}

The manufacturer's instructions were followed (Takara Bio, Japan) and all operations were performed on ice. Two microliter of each of the above reverse-transcribed samples were added to $10 \mu \mathrm{L}$ of TB Green premix Ex Taq II $2 \times, 0.8 \mu \mathrm{l}$ upstream primer, $0.8 \mu \mathrm{L}$ downstream primer, $0.4 \mu \mathrm{L}$ ROX Reference Dye $50 \times$ and $6 \mu \mathrm{L}$ The DEPC water such that the total reaction system was $20 \mu \mathrm{L}$. The real-time PCR reaction procedure was predenaturation at $95^{\circ} \mathrm{C}$ for $30 \mathrm{~s}$, and the PCR reaction was carried out for a total of 42 cycles, each cycle being: $95^{\circ} \mathrm{C}$ for 5 seconds and $59^{\circ} \mathrm{C}$ for $30 \mathrm{~s}$.

Oligonucleotide primers for quantitative RT-PCR analysis of inflammatory factors and Actin housekeeping genes in chicken ileum mucosa are listed in Table 2. Briefly, the CFX Connect Real-Time System (BIO-RAD, USA) and the PrimeScript ${ }^{\mathrm{m}} \mathrm{RT}$ reagent KIT with gDNA Eraser (Stratagene) were used to amplify and detect equal amounts of total RNA from each sample, and a standard curve was generated using $\log 10$ diluted standard RNA. Each analysis was performed in triplicate. To normalize RNA levels between samples within the experiment, the average threshold cycle $(\mathrm{Ct})$ value of the amplified product was calculated by pooling values from all samples in the experiment.

\section{Data analysis}

All data were analyzed with SPSS version17.0 (SPSS Inc., Chicago, IL). A significance level of 0.05 was used. The data of intestinal lesion score were analyzed by one-way ANOVA, and were subjected to grouped table of the GraphPad Prism 5 (GraphPad Software, Inc., CA, USA). Other data were analyzed by two-factorial analysis of variance to examine the main effects of probiotic and challenge, and their interaction using general linear model procedure SPSS 17.0. When a significant interaction between the main effects was observed, Duncan's multiple comparison was used to compare the differences among the four groups. Results in the tables were given as the mean and pooled SEM.

\footnotetext{
Abbreviations

AKP: Alkaline phosphatase; ALB: Albumin; CP: Clostridium perfringens; FRS: Free-range system; GOT: Glutamic oxaloacetic transaminase; IgA: Immunoglobulin A; IgG: Immunoglobulin G; IgM: Immunoglobulin $\mathrm{M}_{\text {; }}$ LP: Lactobacillus plantarum; NE: Necrotic enteritis; NLP: No Lactobacillus plantarum; SPF: Specific pathogen free; SPFC: Specific pathogen free environment + base diet; SPFL: Specific pathogen free environment + Lactobacillus plantarum; TP: Total protein; T-SOD: Total superoxide dismutase; V/C: The ratio of the height of the villi to the depth of the crypt
}

\section{Acknowledgements}

Thanks to Dr. Li Guanhong for his guidance on the experiment and experimental data, and thank the Hu Yongqiang, Zeng Yongdi, Guo Beibei for their help in this experiment.

\section{Authors' contributions}

NZ and TX designed the experiments and wrote the paper; LY, YC, JW, and MH performed the experiments and collected the samples. TX and LY analyzed the data. NZ and TX were responsible for the final content. All of the authors have read and approved the final manuscript.

\section{Funding}

This work was supported by National Natural Science Foundation of China (project no. 3146068; Beijing, P. R. China).

\section{Availability of data and materials}

The dataset supporting the conclusions of this article is included within the article and additional Tables 3, 4, 5, 6, 7, 8, 9 and 10 and Fig. 1.

\section{Ethics approval}

This study was approved by the Animal Care and Use Committee of Jiangxi Agricultural University.

\section{Consent for publication}

Applicable.

\section{Competing interests}

The authors declare that they have no competing interests.

Received: 21 October 2019 Accepted: 24 January 2020

Published online: 07 February 2020

\section{References}

1. Al-Sheikhly F, Truscott RB. The pathology of necrotic enteritis of chickens following infusion of broth cultures of clostridium perfringens into the duodenum. Avian Dis. 1977;21:230-40.

2. Awad WA, Ghareeb K, Abdel-Raheem S, Böhm J. Effects of dietary inclusion of probiotic and synbiotic on growth performance, organ weights, and intestinal histomorphology of broiler chickens. Poult Sci. 2009;88:49-56.

3. Bertran K, Lee D, Criado MF, Smith D, Swayne DE, Pantin-Jackwood MJ. Pathobiology of Tennessee 2017 H7N9 low and high pathogenicity avian influenza viruses in commercial broiler breeders and specific pathogen free layer chickens. Vet Res. 2018;49:82.

4. Biasato I, Ferrocino I, Biasibetti E, Grego E, Dabbou S, Sereno A, et al. Modulation of intestinal microbiota, morphology and mucin composition by dietary insect meal inclusion in free-range chickens. BMC Vet Res. 2018; 14:383.

5. Borruel N. Increased mucosal tumour necrosis factor alpha production in Crohn's disease can be downregulated ex vivo by probiotic bacteria. Gut. 2002:51:659-64

6. Borruel N. Effects of nonpathogenic bacteria on cytokine secretion by human intestinal mucosa. Am J Gastroenterol. 2003:98:865-70.

7. Borruel N, Carol M, Casellas F, Antolín M, de Lara F, Espín E, et al. Increased mucosal tumour necrosis factor \{alpha\} production in Crohn's disease can be downregulated ex vivo by probiotic bacteria. Gut. 2002;51:659-64.

8. Caly DL, D'Inca R, Auclair E, Drider D. Alternatives to antibiotics to prevent necrotic enteritis in broiler chickens: a Microbiologist's perspective. Front Microbiol. 2015;6:1336

9. Campbell DLM, de Haas EN, Lee C. A review of environmental enrichment for laying hens during rearing in relation to their behavioral and physiological development. Poult Sci. 2019;98:9-28.

10. Chen $\mathrm{S}$, Xiang $H$, Zhu $X$, Zhang $H$, Wang D, Liu H, et al. Free dietary choice and free-range rearing improve the product quality, gait score, and microbial richness of chickens. Animals. 2018;8:84.

11. Chielo LI, Pike T, Cooper J. Ranging behaviour of commercial free-range laying hens. Animals. 2016;6:28

12. Cooper KK, Songer JG. Virulence of Clostridium perfringens in an experimental model of poultry necrotic enteritis. Vet Microbiol. 2010;142: 323-8.

13. Cox CM, Dalloul RA. Immunomodulatory role of probiotics in poultry and potential in ovo application. Beneficial Microbe. 2015;6:45-52.

14. Guo S, Liu D, Zhang B, Li Z, Li Y, Ding B, et al. Two lactobacillus species inhibit the growth and a-toxin production of Clostridium perfringens and induced Proinflammatory factors in chicken intestinal epithelial cells in vitro. Front Microbiol. 2017;8:2081. 
15. Han M, Kim J, Jeon E, Lee H, Koo B, Min K, et al. The current epidemiological status of infectious coryza and efficacy of PoulShot Coryza in specific pathogen-free chickens. J Vet Sci. 2016;17:323-30.

16. Hofacre CL, Smith JA, Mathis GF. An optimist's view on limiting necrotic enteritis and maintaining broiler gut health and performance in today's marketing, food safety, and regulatory climate. Poult Sci. 2018;97:1929-33.

17. Immerseel FV, Buck JD, Pasmans F, Huyghebaert G, Haesebrouck F, Ducatelle R. Clostridium perfringens in poultry: an emerging threat for animal and public health. Avian Pathol. 2004;33:537-49.

18. Iskandar S. Laying performance of Wareng chicken under free choice feeding and different cage density. media peternakan. 2011;34:58-63.

19. Kassaa IA, Hamze M, Hober D, Chihib NE, Drider D. Identification of vaginal lactobacilli with potential probiotic properties isolated from women in North Lebanon. Microb Ecol. 2014;67:722-34

20. Keyburn AL, Boyce JD, Vaz P, Bannam TL, Ford ME, Parker D, et al. NetB, a new toxin that is associated with avian necrotic enteritis caused by Clostridium perfringens. PLoS Pathog. 2008:4:e26.

21. Kikuchi Y, Kunitoh-Asari A, Hayakawa K, Imai S, Kasuya K, Abe K, et al. Oral administration of Lactobacillus plantarum strain AYA enhances IgA secretion and provides survival protection against influenza virus infection in mice. PLoS One. 2014:9:e86416.

22. Lemos Teixeira D, Larraín R, Hötzel MJ. Are views towards egg farming associated with Brazilian and Chilean egg consumers' purchasing habits? PLoS One. 2018;13:e203867.

23. Li Z, Wang W, Liu D, Guo Y. Effects of lactobacillus acidophilus on the growth performance and intestinal health of broilers challenged with Clostridium perfringens. J Anim Sci Biotechno. 2018;9:10-25.

24. Lovland A, Kaldhusdal M. Severely impaired production performance in broiler flocks with high incidence of Clostridium perfringens-associated hepatitis. Avian Pathol. 2001;30:73-81.

25. McDevitt RM, Brooker JD, Acamovic T, Sparks NHC. Necrotic enteritis; a continuing challenge for the poultry industry. Worlds Poult Sci J. 2006;62:221-47.

26. M'Sadeq SA, Wu S, Swick RA, Choct M. Towards the control of necrotic enteritis in broiler chickens with in-feed antibiotics phasing-out worldwide. Anim Nutr. 2015;1:1-11.

27. Neal-McKinney JM, Lu X, Duong T, Larson CL, Call DR, Shah DH, et al. Production of organic acids by probiotic lactobacilli can be used to reduce pathogen load in poultry. PLoS One. 2012;7:e43928.

28. Neveling DP, van Emmenes L, Ahire JJ, Pieterse E, Smith C, Dicks L. Safety assessment of antibiotic and probiotic feed additives for Gallus Gallus domesticus. Sci Rep. 2017;7:12767.

29. Ng SC, Hart AL, Kamm MA, Stagg AJ, Knight SC. Mechanisms of action of probiotics: recent advances. Inflamm Bowel Dis. 2009;15:300-10.

30. Noto Llana M, Sarnacki SH, Aya Castañeda MDR, Bernal Ml, Giacomodonato MN, Cerquetti MC. Consumption of lactobacillus casei fermented milk prevents salmonella reactive arthritis by modulating IL-23/IL-17 expression. PLoS One. 2013:8:e82588.

31. Prescott JF, Smyth JA, Shojadoost B, Vince A. Experimental reproduction of necrotic enteritis in chickens: a review. Avian Pathol. 2016:45:317-22.

32. Rezzani R, Nardo L, Favero G, Peroni M, Rodella LF. Thymus and aging: morphological, radiological, and functional overview. Age. 2013;36:313-51.

33. Shojadoost B, Vince AR, Prescott JF. The successful experimental induction of necrotic enteritis in chickens by Clostridium perfringens: a critical review. Vet Res. 2012;43:74.

34. Smyth JA. Pathology and diagnosis of necrotic enteritis: is it clear-cut? Avian Pathol. 2016:45:282-7.

35. Souillard R, Répérant J, Experton C, Huneau-Salaun A, Coton J, Balaine L, et al. Husbandry practices, health, and welfare status of organic broilers in France. Animals. 2019;9:97.

36. Tejero-Sarinena S, Barlow J, Costabile A, Gibson GR, Rowland I. In vitro evaluation of the antimicrobial activity of a range of probiotics against pathogens: evidence for the effects of organic acids. Anaerobe. 2012;18:530-8.

37. Tharmaraj N, Shah NP. Antimicrobial effects of probiotic bacteria against selected species of yeasts and moulds in cheese-based dips. Int J Food Sci Technol. 2010;44:1916-26.

38. Van Immerseel F, De Buck J, Pasmans F, Huyghebaert G, Haesebrouck F Ducatelle R. Clostridium perfringens in poultry: an emerging threat for animal and public health. Avian Pathol. 2004;33:537-49.

39. Van Immerseel F, Rood Jl, Moore RJ, Titball RW. Rethinking our understanding of the pathogenesis of necrotic enteritis in chickens. Trends Microbiol. 2008;17:32-6.
40. Wang H, Ni X, Qing X, Liu L, Lai J, Khalique A, et al. Probiotic enhanced intestinal immunity in broilers against subclinical necrotic enteritis. Front Immunol. 2017;8:1592.

41. Wang T, Teng K, Liu Y, Shi W, Zhang J, Dong E, et al. Lactobacillus plantarum PFM 105 promotes intestinal development through modulation of gut microbiota in weaning piglets. Front Microbiol. 2019;10:90.

42. Wang $Y$, Jiang $Z$, Jin $Z$, Tan $H, X u B$. Risk factors for infectious diseases in backyard poultry farms in the Poyang Lake area, China. PLoS One. 2013;8: e67366.

\section{Publisher's Note}

Springer Nature remains neutral with regard to jurisdictional claims in published maps and institutional affiliations.
Ready to submit your research? Choose BMC and benefit from:

- fast, convenient online submission

- thorough peer review by experienced researchers in your field

- rapid publication on acceptance

- support for research data, including large and complex data types

- gold Open Access which fosters wider collaboration and increased citations

- maximum visibility for your research: over $100 \mathrm{M}$ website views per year

At BMC, research is always in progress.

Learn more biomedcentral.com/submissions 